\title{
Research on Teaching Achievements Transformation with Creative Market as a Carrier*
}

\author{
Dehui Ye \\ School of Art \& Design \\ Guilin University of Electronic Technology \\ Guilin, China 541004
}

\author{
Xiongyan Yang \\ School of Arts \& Design \\ Guilin University of Electronic Technology \\ Guilin, China 541004
}

\author{
Yuanyuan Tan \\ School of Art \& Design \\ Guilin University of Electronic Technology \\ Guilin, China 541004
}

\begin{abstract}
Creative market teaching has become a new undergraduate practical teaching method, which provides a show and exchange platform for students so as to enhance their motivation and enthusiasm for creation. In addition, by studying the exhibition sales model and current situation, teachers can put forward the idea of transformation of the creative market teaching achievements and use the internet platform to tie the "thinking creation, doing creation and showing creation" stages together, centering on the active task. In this way, the creative market interactions can be combined with the specialized courses to improve students' ability of practice.
\end{abstract}

Keywords-creative market; Internet plus; practical teaching; achievement transformation

\section{INTRODUCTION}

Under the background of "nationwide entrepreneurship and popular innovation", creative market is developing in full swing. In addition, there is a lack of practical teaching for students in arts and design in colleges and universities, resulting in low completeness of involvement in their majors. Under the circumstances, the creative market teaching based on internet platform, centering on the actual project tasks, can realize integration of curriculum resources and help students transform their work into merchandise to improve their creative enthusiasm, thus it has certain practical significance in improving students' professional practice ability.

\section{CURRENT SitUATION OF IMPLEMENTATION OF CREATIVE MARKET}

In many European cities, creative market has become a part of the charm of the city, the birthplace of street fashion and also the starting point of the careers of many talented original

*[Fund Project]: 2016 Teaching Reform Major Project of School Level of Guilin University of Electronic Technology (JGA201601), 2017 Guangxi Higher Education Undergraduate Teaching Reform Project-Class A (2017JGA201), 2018 Guangxi Academic Degree and Postgraduate Teaching Reform Project (JGY2018060)

[CLC number]: J06. artists and designers. At present, the main form of creative market is to provide street booths for young people to show their creative products. Young people can rent a booth at a relatively low price or even get a booth for free to exhibit and sell their creative goods [1]. In university campus, the creative market, with its low threshold, low risk, economy, practicability and uniqueness, is attracting students to get involved, where they can sell their handmade products of creativity to get economic benefit. The activities in the creative market mainly include exhibition, customization, sales, auction and field fabrication of creative works. The creative market in university campus is developing rapidly, and attracts college students with high enthusiasm to participate, thus achieving good result and great social influence.

\section{A. Exhibition Sales Model in the Creative Market}

Exhibition sales model in the creative market mainly include booth mode, lattice shop mode and network mode [2]. Among them, the booth mode is currently the most primitive and also the most important operation mode of creative market activities, which is similar to a trade fair and the creative producers can apply for or get invitation for participation. The booth mode market requires sales of finished creative product, which means high investment in product pre-production, promotion, exhibition sales, etc., so it poses a high income risk In addition, some creative markets held irregularly in fixed city art communities also have a certain influence and appeal, such as Beijing 798 Art District creative market, Guangzhou Redtory Art \& Design Factory creative market and Shenzhen OCT LOFT. The lattice shop mode means putting a "lattice cabinet" of standard size in the shops in the busy area of a city, so that the creative producers can rent the lattice cabinet at a low price per month to sell their products, and different exhibition units are for different types of products and users. The "lattice shop" has the characteristics of wide range of applicable group and low cost, etc., as it does not need to organize the supply of products, all goods are provided directly by customers, and the shop only needs to provide the storefront, the cabinet and corresponding management. The 
lattice shop sale on consignment has now become a low entry channel of entrepreneurship for young creative people, and physical stores of lattice shop can be found in many cities of China and they also have flexible operation mode.

In the age of internet + , online shopping has become the main shopping way for young people, and e-commerce and online platforms are increasingly diversified and mature, which lays a solid foundation for online operation of creative market. The network mode of creative market is relatively abundant, and the common network mode of creative market is integrated service platform. The relatively mature domestic creative market service platforms mainly include the Crazy Fruit creative market, the iMART creative market, the Candy Box consignment system, etc. The Crazy Fruit web is currently the most online creative market in China, and its offline activities brand the Crazy Fruit creative market has great influence in the country, and has organized or participated in many creative market activities throughout the country since its founding. iMART creative market was sponsored by City Pictorial in July 2006, and is China's first large-scale creativity exchange platform aimed at young people. "IMART", short for "I am art" (everyone is an artist), is a test platform which produces creativity and commercialize the creative works. Both the Crazy Fruit creative market and the iMART creative market carry out the booth mode, box consignment mode and the network mode in the same time and achieve good sales and propaganda effects. The three modes of "creative market" are interdependent and each has its own advantages. The "Box consignment mode" as the "physical store" of the original brand is to build brand image; the "Internet mode" realizes the overall exhibition of the brand to provide a deeper platform for audience; and the "booth mode", similar to the "signing session" of the creative producer, can increase brand affinity and obtain direct information feedback so as to facilitate the innovation and development of the brand.

\section{B. Current Situation of Creative Market in Campus}

1) Cases of influential campus creative market: Many colleges and universities in China have also carried out creative market activities with unique characteristics so as to create a good entrepreneurial atmosphere and provide a better practical platform for college students. For example, Taiyuan University of Technology undergraduate creative market, as the practical platform of innovation and entrepreneurship education of Taiyuan University of Technology, has been held for successive six years since 2016, and there are about 200 booths in the creative market each year, showing nearly 5000 pieces of works. A large-scale creative market brings great influence. In the creative market, students can sell their handmade design works, and their works based on their design schemes also can be produced in batch and enter the market as the merchandise. In this way, the whole process from design idea to design draft to material object and finally to merchandise is right for the teaching purpose and reflects the pragmatic education. Guangxi Arts University creative market has been held for successive 16 years, and includes the original creative products zone, artwork zone, DIY interactive zone, folk culture performance zone, the ancient Zhuang characters creative poster exhibition zone, etc., which receives high attention from media, creates good social influence and can facilitate the employment of students.

2) Problems of campus creative market: Although various campus creative markets are growing vigorously, and the pattern of activities is also growing larger, there are still some problems in campus creative markets based on the activity conditions. Most campus creative market activities are less original and serious homogeneous. Some creative markets have become common commodity marketing activities. What's more, in the process of product sales, team awareness and lack of organizational capabilities are more prominent [3].

a) Creative market activities are completely disconnected from professional practice teaching: At present, many colleges and universities in China have the creative market activities, but most of them are held by the club activity of college students' union. The main content of activities is selling general goods, the nature of which tends to be that of extracurricular activities. The creative market model should be combined with professional practice teaching, which is an extension of practice teaching in professional classroom. After the classroom teaching and after-school evaluation are closely related with market demand, the creative market teaching is more targeted, the activities has more adequate prepare, and the significance of market activities is more prominent.

b) Operation and management mechanism of creative market model: At present, most of the creative markets in colleges and universities belong to the club management of student unions. Due to various reasons such as graduation and the change of clubs, the continuous and effective activities of creative market are affected. The lack of long-term management mechanism is not conducive to the regular and steady development of creative market; the market lacks access mechanism, return and exchange mechanism and propaganda mechanism.

c) The creative market activities is lack of connotation, and the original features are not distinct: There is a lack of professional practical teaching guidance and systematic organization and management in many campus creative markets. The works are uneven in quality, and lack of originality, refinement and perfection. During the process of implementation, it is lack of effective school-enterprise cooperation mechanism; and the construction of service platform do not integrate all factors such as enterprises, professional teachers and college students, which is lack of the evaluation system of all parties. Therefore, the cultivation is discounted in the students' professional practice ability, professional innovation ability and entrepreneurial ability. In addition, there are few supports of technical support and brand building in the follow-up of creative market activities.

Although the creative market activities on campus have achieved good results, most of them are still at the level of club activities, and there are some problems that the cultivation of applied talents' innovative and entrepreneurial ability cannot 
achieve the desired effect. Therefore, it is of practical significance to carry out creative market teaching, combine teaching with market activities, and promote the transformation of classroom teaching results.

\section{SIGNIFICANCE OF TRANSFORMATION OF CREATIVE MARKET TEACHING RESULTS}

The "creative market" activity is a pattern of manifestation of the real market, requiring authentic design works to be presented and having some value before being recognized [4]. It is not easy to transform paper design into physical objects. With the established goals, the students must think about the links of production and production, including the internal structure of their works. This mode can make students' paper creativity be tested in reality. And the "creative market" is a good practice and test for students of art and design majors.

\section{A. Creative Market Teaching Strengthens Practice Teaching, and Provides an Exchange and Display Platform for Practical Teaching}

The creative market teaching is essentially a maker teaching, which is targeted to a specific problem. And it is a problem-oriented educational mode [5] that solves problems creatively through interrelated resources, skills and technology. Creative market teaching is based on the "pragmatic" educational philosophy, and embodies the educational concept of "combining theory with practice". With the construction of creative market resources and product display platform combined with Internet platform, through the way of campus market, the students are encouraged to develop original products and build a good platform for students' practice. As an effective supplement and reference practice to the system reform, creative market teaching has great flexibility and affinity. And domestic design education is rather weak in practice, and many practical activities are mere formality. The combination of creative market teaching and professional courses integrates some basic design courses and design practice ones. The market feedback is obtained through some "creative market" activities with themes, so as to make up for the lack of cooperative design projects between universities and enterprises, enhance the flexibility and purpose of teaching practice, and achieve the effect of learning for practical purposes. According to the Pyramid theory of learning efficiency, the knowledge absorption by "learning by doing" reaches $75 \%$, and "immediate application" reaches $90 \%$. So the comprehensive effect of creative market teaching is more prominent.

\section{B. Creative Market Teaching Transforms "Works" into "Goods" to Enhance Students' Creative Enthusiasm}

The creative students make use of the knowledge that they have learned in the classroom to make the product, or translate the homework into the product directly, so as to achieve the goal of "changing works into goods and turning ideas into benefits". The works designed by students are no longer stayed in a corner of the classroom, but are vividly shown on the stalls and showcases of the handmade creative markets for exchange and sell. Consumers who like these original works can get close contact with them, and the cost of student investment can be rewarded in a certain way, which is conducive to students creative enthusiasm. In addition, the factors that affect the quality of products are not only the quality of products, but also the creativity, production, packaging and marketing, all of which relate to creativity, skills and talents of product makers. Unusual but wonderful thinking makes the design realize the function transformation and the value promotion, to develop the students' creative thinking and creative practice ability, and transform the creativity into the target effectively. The purpose is to stimulate students' consciousness, initiative and creativity in students' growth and development.

\section{TEACHING IMPLEMENTATION AND ACHIEVEMENT} TRANSFORMATION WITH CREATIVE MARKET AS THE CARRIER

\section{A. The Idea of Transformation of Teaching Results with Creative Market as the Carrier}

In the actual teaching process of creative market, the idea of transformation of teaching results affects the direction and teaching effect of creative market teaching. There are the following aspects in the idea of transformation of teaching results.

1) Introducing project management and promoting efficiency of result transformation: In the creative marketplace teaching, one or more projects are taken as the cases for product development [7], involving design, research and development, processing and sales. In traditional teaching, the teaching of art and design majors is mainly creative design, with the creation of effect pictures. Most coursework stays on the effect-picture level, and the students are less involved in the product development process in the teaching process. Creative market teaching runs through the whole process of creative product development, involving many links. In this process, students are not only in drawing, but also in production, processing and sales, which needs teamwork and effective management of projects/ products. Therefore, we introduce project management content, use QQ group and WeChat to carry out project management and supervise the design process, including the selections of creative schemes, materials, processing technologies, suppliers and sales channels. It is necessary that teachers shall give professional guidance to improve the efficiency of teaching results.

2) Making full use of school processing resources: Most of arts and design majors are equipped with related processing equipment and tools, and the related studios are opened up to students for improving the utilization efficiency of all kinds of processing equipment in the school. The teaching and making practice of creative market is more important. And the students should be able to use advanced manufacturing technology to develop creative small products, such as carving technology, molding, screen printing, NC machining and $3 \mathrm{D}$ printing. So that the students can be familiar with technology and materials, and the production process and links, so as to complete the production of physical products and turn creativity into real products. 


\section{B. Teaching Practice Based on Internet plus Creative Market}

The teaching practice based on Internet + creative market runs through the stages of "Create ideas, make ideas and show ideas" through the Internet platform, following the process of design idea creation, practice and display. Selective implementation of creative market teaching is carried out according to the nature of course and the conditions for its implementation. And we can implement the whole process of creative market teaching in a curriculum. The integrity of creative market teaching is good, and the production progress is easy to control with a short production cycle. It is suitable for short and fast creative product production, such as small ornaments making and graffiti products; it can also link up several courses to complete the practice of creative market project, each course taking different division of labor and process link. This type of creative market teaching requires more collaboration and is suitable for the production of complex creative products with longer cycle.

1) "Create ideas" stage: "Create ideas" mainly includes two links: market Research and positioning analysis. Market research is more important in creative market teaching, which is the first step in finding demand. Design works are often self describing and painting in conventional teaching, and few of students are able to conduct questionnaire surveys under the restriction of time and energy. Their market research is often formalistic and of no practical significance. And their product design process starts with sketches, terminating in the rendering, resulting in the lack of persuasive power. During the creative market teaching, if the students want their works get the favor and approval in the actual market, they have to conscientiously carry out the market investigation and excavate the real demand [8]. The investigation includes the survey of audiences, raw materials, manufacturing and processing market, and sales market. Moreover, the investigation channels are combined with field investigation and network investigation.

In the link of positioning analysis, campus creative market teaching is mainly about active water.

To highlight the characteristics and personalization characteristics, it is necessary to analyze the regional characteristic resources and the actual consumption demand of consumer groups. This subject has two main attempts in this respect: first, combining local traditional handicraft industry and exploring featured resources for product creation. This subject not only has economic significance, but also has certain social value, such as Zhuang brocade craft in Guangxi, Naxing pottery craft, shell carving craft, etc. Combined with modern design means, Internet technology and platform, by the method of "traditional redesign", the traditional products are given new connotation, and then the products can be made by hands and sold. Two, according to the actual needs of contemporary college students, it is necessary to meet the personality differences and emotional psychological experience of consumers, for example, customized handmade products, experiential decorative trinkets, high-tech smart small products, which the students are more familiar with, and more active to make; and these products are simple in structure and convenient for production and processing.

2) "Make ideas" stage: The content of "Make ideas" is the stage of creative practice, which determines the content of the course with specific tasks and emphasizes hands-on practice. And it can be carried out in both professional foundation and professional courses. For the three major constituent courses in the basic courses, in the theme form of "creative market", we can combine the plane structure, threedimensional structure, color composition and basic design, so as to establish the creative market teaching course group. We shall set up specific tasks to ensure the integrity of teaching and choose diversified materials in life such as ceramic, glass, plastic, wood, knitted fabric, iron, copper and silver; and through the modern design methods, the material is reprocessed, spliced, assembled, and displayed through different means such as colors, shapes, cutting, collage and so on. Design works that are different from common decorations in life, not flashy and conceptual works. In practice, we should grasp theoretical knowledge, find problems, analyze problems and solve problems.

In terms of professional courses, we can choose comprehensive courses according to different professional courses, and set specific tasks for implementation, such as graphic design's illustration design, T-shirt design, animation major's animation derivative products, graffiti products, industrial Design's creative jewelry design, and fashion design major's custom tailored clothes design, and decorative arts' oil painting and traditional Chinese painting. In the creative market teaching practice of different professional courses, creative products are made according to professional positioning and actual market demand. In the realization link of product creativity, the scheme of creative market teaching mode can be processed by the processing equipment resources of the school to improve the efficiency of utilization of production equipment. We can also find a small-batch lowcost production channels for small batch production.

3) "Show ideas" stage: The "Show ideas" stage is the exhibition and sales stage of creative market teaching. During this stage, we use the wide spread channels of the Internet platform to carry out multi-directional publicity, display and sales. In addition, combined with the three modes of "creative market", the "booth mode" in campus is carried out regularly to exhibit and sell physical products. So than we have a dace to face communication with university students and collect feedback so as to improve the products in the later stage. The network sale is carried out on the Crazy Fruit creative market, the iMART creative market, the Candy Box consignment system and other websites. And the biggest advantage of network mode lies in - first sale and then production, ondemand customization and zero inventory. If you are convenient, you can go to the "Lattice Shop" physical store to rent the lattice space for sales. In addition, we can also build our own WeChat official accounts, QQ group, weibo for product publicity and sales. After the product has been approved in the early stage, creative people can try the crowd 
raising mode, publishing fundraising projects through the Internet or SNS to raise funds. The risk assessment of investors not only solve the most difficult problemsprocessing funds and sales channels in this study, but also help to expand the scale of production.

\section{CONCLUSION}

Creative marketplace teaching is a new attempt of teaching in colleges and universities, which takes the design and production of practical tasks as the main line and transforms works into products. And students are more active in the degree of participation and creative enthusiasm in the professional courses, and it is of great significance for the training of applied talents through multidirectional propaganda and sale in combination with the Internet platforms.

\section{REFERENCES}

[1] Yan Libing. Analysis on Current Situation and Development Strategy of Xiamen Creative Market [J]. Journal of Mudanjiang University, 2013,06:85-86. 颜莉冰. 厦门市创意市集现状及发展策略分析[J]. 牡 丹江大学学报,2013,06:85-86

[2] Xing Jiali. Creatice Transfer[D]. Capital Normal University,2009. 行佳 丽. 创意转呈[D].首都师范大学, 2009 .

[3] Lei Junxia. Research and Practice on Cultivation of Innovative and Entrepreneurial Abilities of Art and Design Majors in Higher Vocational Colleges Under Practice Teaching Mode of Creative Market [J]. Packaging World,2016,02:43-45. 雷俊霞. 创意市集实践教学模式 下高职艺术设计类专业创新创业能力培养的研究与实践 [J]. 包装 世界,2016,02:43-45.

[4] Xiao Jin. Feasibility Analysis on Application of "Creative Market" on Industrial Design Education [J]. Art Education, 2012,03:32-34. 肖瑾. “创意市集”应用于工业设计教育的可行性分析 [J]. 艺术教 育, 2012,03:32-34

[5] Wu Qing. Research on Practical Teaching of Industrial Design in Higher Vocational Colleges in Way of Makers [J]. Light Industry Science and Technology, 2016,03:156-157. 吴青. 创客式高职工业设 计实践教学探究[J]. 轻工科技,2016,03:156-157.

[6] Jiang Yiwei. Research on Commercialization of Industrial Design Ideas in Colleges [D]. 2008. 姜炎炎威. 高校工业设计创意商品化方式研究 [D].中国美术学院,2008.

[7] Cai Mincheng. Application of "Creative Market" Courses [D]. Nanjing University of the Arts,2010. 蔡敏成. “创意市集”类型课程的应用[D]. 南京艺术学院,2010.

[8] Zhong Lisheng, Zou Jie. Analysis on Commercializing Conditions and Paths of Teaching Achievements of Art Major in Colleges [J]. Art Panorama2012,11:158-159. 钟立生,邹洁. 高校艺术专业教学成果市 场化条件与路径探析 [J]. 美术大观,2012,11:158-159. 